\title{
TRANSLATOR'S PREFACE
}

\author{
[MAUREEN B. FANT]
}

One very good reason to learn the Italian language is to enjoy the works of Oretta Zanini De Vita in the original. In fact, it's a very good reason to study Italian geography, literature, and history. Writing with humor and charm, Oretta thinks nothing of reporting the opinion of a four-hundred-year-old author as though she had just put down the telephone, and sends the reader to the remotest villages of the most distant alpine valleys as though they were marked in bold on any map. In other words, she puts even educated Italian readers through their paces-with a smile.

To make the going easier for English-language readers, Oretta and I have added a glossary (including notes on translation choices), a bibliography, and many new notes and explanations in the text. To cover everything, however, would have made this an encyclopedia of Italian culture, not a biography of 3ro traditional pasta shapes and their innumerable variations. Readers who want to follow up on the many allusions can do so easily in any number of reference books and atlases, while those who just want to know what a pasta shape is like, where it is or was made, and some of the names by which it is called will find all they need in these pages - along with plenty of folklore, anecdotes, literary excerpts, and the author's opinions.

A few aspects of the translation warrant explanation.

PASTA NAMES. The star of this book is the pasta shape. Each entry heading is the principal name by which a given pasta shape or group of similar, or similarly named, shapes is known. Other names for the same or similar shape are given in the text. Sometimes the names are normal Italian words used fancifully, such as spaghetti. A speaker of Italian knows this means "little strings," even if a ball of twine is not the first thing that springs to mind. But most Italian speakers would not know that, say, blecs means "patches" without reading the text. Where there 
is a clear and literal Italian meaning for a pasta name, its English translation is usually given at the beginning of the Remarks section of each pasta entry. Where the pasta name is a dialect word or otherwise requires lengthy explanation, this is covered in Remarks as well. Sometimes nobody knows what a pasta name means or what its etymology is. In other words, English- and Italian-language readers are often in the same boat.

Some pasta names are both specific enough to have their own entries and comprehensive enough to be used generically. Where translation would not be too forced, I have tried to use English equivalents (noodle or flat noodle instead of tagliatella) in the text, but in most cases anyone reading this book will understand that ravioli are something stuffed and spaghetti something stringy.

It is impossible to translate all the entry headings even into standard Italian, much less into English. Therefore, in order to give some quick idea of what an entry is like, Oretta and I formulated six broad categories of pasta shapes and assigned one of them to each entry heading:

- pasta corta Short forms, both factory made and homemade, such as penne or rigatoni, but also, say, handmade trofie.

- pasta lunga Long forms, such as spaghetti and tagliatelle, of course, as well as handmade shapes, such as pici.

- pasta ripiena Stuffed pasta, that is, ravioli and the like, as well as, rarely, certain pastas layered with sauce and baked, such as vincisgrassi.

- pastina Tiny shapes that are cooked in broth.

- gnocchi/gnocchetti Usually small, dumplinglike forms, but also some rustic long forms.

- strascinati Variations on the traditionally handmade, and today also factorymade, pasta disk dragged - strascinato - across a wooden board by hand or with the aid of a traditional utensil. Orecchiette are the most famous example.

Names that can apply to many shapes, such as maccheroni and lasagne, are so labeled, and shapes that cannot be shoehorned into any of the six classifications are designated "unusual shape." The category assignments should often not be taken too literally: one man's gnocchetto may be another man's strascinato. This is not an exact science. An index of pasta names, including the alternative names for the entry headings as well as other pastas mentioned, is given at the end of the book.

GEOGRAPHIC DIVISIONS. Readers who wish to follow the pasta shapes around their home territories would be well advised to keep a detailed atlas of Italy to hand, such as those published by the Touring Club Italiano. After only a few pages of this book, it will be clear that the important geographic divisions are val- 
leys, hills or mountains, segments of the seacoast, lakeshores, or some other area formed by physical features, often obscure, rather than by political boundaries. Place names without precise political boundaries, especially river valleys, often lack clear-cut names in Italian. And Italian editorial (and probably cartographic) usage values nuance over the consistency so relentlessly pursued by the Englishspeaking world. In choosing to translate, or not, the names of the valleys so important to this book, I have tried to adopt the form a reader is most likely to find in the index of a good atlas of Italy. Sometimes only the name of the river will be listed, sometimes the valley (as one, two, or three words, sometimes under $V$, sometimes under the name of the river). Speaking solely of river names, only the Tiber, Tevere in Italian, has an English translation.

A word about Italy's political divisions is also needed. The present-day Republic of Italy has twenty regioni, or "regions," most of whose boundaries date to the I970s, some later. The gastronomic divisions of Italy do not, however, always correspond to the modern map, and regional attributions should never be taken too literally. Also, some Italian regions have been formed from more than one geographic entity, such as Emilia-Romagna or Friuli-Venezia Giulia, and others that were formerly joined have been split into two regions, such as Abruzzo and Molise. The regions of Sicily and Sardinia each comprise numerous islands, not just the large ones.

Adding to the complexity are the ancient regional names, traditionally dragged in to serve as English equivalents of Italian. Examples are Latium, an ancient region that only partially corresponds to the modern Lazio, and ancient Calabria, which has nothing whatsoever to do with its modern namesake, an area roughly equivalent to the ancient Bruttium.

Where only half the name of a double region appears, it is not an omission. In fact, only that half is meant_- "Emilia" alone means only the Emilia half of the region (where Bologna and Modena are located); "Romagna" used alone means only the piece on the Adriatic side, where Rimini and Ravenna are the best-known cities. "Friuli" means the northwest part of the region of Friuli-Venezia Giulia, and "Venezia Giulia" refers only to the southeastern part (which contains the regional capital and most famous city, Trieste).

Beneath the regional level come the provinces, each bearing the name of its capital city. Municipalities are subdivided into any number of villages, towns, frazioni (fractions), and borghi (hamlets). Unless it is obvious that the urban area is meant, all names of cities should be taken to include their surrounding area, possibly as far as the provincial boundaries.

The names of regions are given in English where English equivalents exist, otherwise in Italian, but not Latin. Only the names of the largest cities, whose English names are household words, are translated. For the adjective form of all place names, I have preferred to use English. 
SAINTS' AND FEAST DAys. Saints' names are given in English except when they are part of an Italian proper name, such as a place name or a church name, or when a saint's English equivalent is either nonexistent or highly obscure.

MEASUREMENTS. Inch equivalents are given with the original centimeters, but are rounded off because the precise sounding " $5 \mathrm{~cm}$ " really just means "a couple of inches" in the home kitchen.

ORGANIZATION OF THE вOOK. Each entry, corresponding to a pasta shape, is divided as follows.

INGREDIENTS: This is a list of the usual traditional ingredients. If it sometimes seems vague or ambiguous, it is because people used what they could lay hands on.

HOW MADE: This is descriptive of traditional methods. It is not (necessarily) intended as a recipe.

ALSO KNOWN AS: Almost all the pastas are known by many, many names. No list can be exhaustive.

HOW SERVED: The principal traditional ways are included. Modern chefs are devising all kinds of new ways to serve traditional pastas, but that is for another book.

WHERE FOUnd: Again, these are the main places. Comprehensiveness is not possible. Lovers of parallel lists - all provinces, all cities-will have to loosen up here. The list of sightings of a given pasta may well consist of a region, the outskirts of a city in a different region, and a valley somewhere. In cases in which a pasta is found throughout Italy without clear associations with a given place, it is noted as "widespread."

REMARKS: These are notes on the shape's history, documentation, literary allusions, etymology, folklore, and anecdotes.

Oretta and I consider ourselves very fortunate indeed that our book is being published by University of California Press and thank Darra Goldstein, Sheila Levine, and Dore Brown for their wise and good-humored counsel throughout the months of translation and editing. As we prepared the draft, we often wondered who they could possibly find to copyedit a book like this, with its history, its geography, its literature, and its rolling and twisting of dough into the most outlandish shapes. Oretta doubted that a single copyeditor could combine the culinary expertise and cultural breadth needed for the task, while I feared that no one could possibly have the strength, patience, and restraint I knew the job required. But there was no need to worry. We are obliged to the press for assigning just 
such a jewel, Sharon Silva, of whom we are in awe and to whom we are profoundly grateful.

Oretta Zanini De Vita has been my friend here in Rome for more than twenty years, and much of what I know about Italian food and its history has come from listening to Oretta talk and from translating her work. She is the classic walking encyclopedia of Italian social history and so much more, and gives her pearls for the asking. It would be hard to find another person so well suited to this topic, and it has been a privilege for me to help bring her work to an international readership.

And speaking of walking encyclopedias, my friend Leofranc Holford-Strevens, in Oxford, has replied within minutes to all my most desperate e-mail queries on everything from Albanian diacritical marks to Greek citations. Thanks, too, as always, to the irreplaceable Howard Isaacs, my partner for the 1998 Dictionary of Italian Cuisine. I could never have translated this book without that earlier work, and I blessed him every time I found exactly the term I sought over these last months. And of course I have been greatly helped by my husband, Francesco Filippi, whose passion for pasta takes second place to no man's. 
This page left intentionally blank 